\title{
Can Rumor Clarification Eliminate the Effects of Rumors? Evidence From China
}

\author{
Peinan Ji, Harbin Institute of Technology, Harbin, China \\ Xiangbin Yan, University of Science and Technology Beijing, Beijing, China \\ Guang Yu, Harbin Institute of Technology, Harbin, China
}

\begin{abstract}
This article analyzes the effects of rumor and official rumor clarification on Chinese stock returns under different rumor conditions using an event study. The results are based on a sample of 832 rumor clarification announcements from China Listed Companies spanning the period of 2015 to 2017. The results show that the average cumulative abnormal return after the rumor event is significantly positive in the positive rumor sample and neutral sample, and significantly negative in the negative rumor sample. After the clarification announcements, we find the announcements effective for the positive and neutral rumor sample, but not in the case of the negative sample. However, by comparing different clarification times of each sample, we find that the earlier the clarification time is, the smaller the impact on the companies in positive and negative rumor examples.
\end{abstract}

\section{KEYWORDS}

Event Study, Rumor Clarification, Rumors, Stock Price

\section{INTRODUCTION}

It is difficult to dispute that rumors have an important influence on corporate value, namely stock prices. Phrases like "Stock X soared amidst rumors of ..." can be read or heard almost daily in the popular media. In recent years, the Internet has proven a productive incubator of rumors (Van Bommel, 2003). Investors exchange information in chatrooms, newsgroups, and message boards. Rumors can also spread through word of mouth or newsletters. Kapferer defines a rumor as the emergence and spreading of information in a societal organism that either has not been yet publicly confirmed or been denied by official sources (Kapferer, 1996). At the same time, the influence of rumors on the company has also been increasingly concerned by researchers and practitioners. The rumors of listed companies caused abnormal volatility in stock prices (Lim and Kong, 2004), increased the operating risk of listed companies (Kiymaz, 2002), and had a certain impact on the stability of the securities market.

For a long time, limiting the spread of rumors in online social networks (OSN) has been an important but difficult problem to be addressed. There are mainly two ways to solve this problem 
currently 1) blocking rumors at the most influential users or community bridges, or 2) spreading truths to clarify the rumors (Wen et al., 2014). Both methods claim to have better results according to their own considerations and environments. However, for most companies, it is the easiest and quickest way to publish rumor clarifications announcements, as well as the lower technical requirements. Previous studies have shown that rumors can have a big impact on the market, resulting in abnormal fluctuations in stocks and yield positive abnormal returns (Yang and Luo, 2014). However, the existing research seldom involves the performance of the company's stock price after the clarification or denial of rumors. This study therefore attempts to investigate the validity of the stock market after the company clarifies the announcement.

Empirical research shows that stock prices react differently to company news accordingly concerning corporate or market conditions (Below and Johnson, 1996; Docking and Koch, 2005; Lee, Kuo, and Yen, 2011; Mian and Sankaraguruswamy, 2008). In recent years, a growing number of researchers are beginning to pay attention to the impact of news on the company, such as reducing information asymmetry between shareholders and firms to improve the efficiency of financial markets. Meanwhile, the financial market is an ideal place for rumors and their dissemination for several reasons: the number of participants is limited, the actors are all experts in the field and flooded with news, time is crucial, and a financial risk is always involved (Schindler, 2003). As a result, research on rumors and rumor restricting in the financial markets has been increasingly concerned by scholars.

For the following three reasons, our research focuses on a developing country, China. First, the securities market in China is full of rumors which are easier to collect. There are a large number of speculators in China's stock market and they believe there are a lot of information leakage and insider transactions in the stock market; therefore, it is reasonable for domestic investors to take rumors into account in their equity investment decisions, in contrast to investors in markets where information leakage is strictly forbidden. In addition, in the case of asymmetric information, speculators have an incentive to influence investors' decisions by creating and spreading rumors.

Second, starting in 2007, the China Securities Regulatory Commission (CSRC) issued a new rule, the Administrative Measures on Information Disclosure by Listed Companies, which applies to all firms listed on the Shanghai Stock Exchange (SHSE) and the Shenzhen Stock Exchange (SZSE). It stipulates that all the listed companies should promptly clarify rumor announcement when there are rumors. The implementation of this new rules and regulations provides an ideal way to observe the influence of rumor clarification on the performance of the company's stock price using event-analysis.

Third, this paper extends the analysis to the Chinese stock market, which is different from the other developed countries' stock market, including both Shanghai and Shenzhen Stock Exchanges and provides new insights into developing equity markets. There are only a few institutional investors in China's A markets with a large number of individual investors (Green, 2003). One of the biggest problems facing traders is lack of transparency. The corporate announcement requirements of listed companies in China are neither perfect nor well developed, and significantly less comprehensive compared with the financial markets of developed countries. Therefore, the trading behavior of investors in China financial market is inconsistent with those in other developed markets. By following the market consensus, investors can make investment decisions according to others who may be more aware of the development of the market. Given the growing significance of China's stock market, along with its unique microstructure features and traders coping with a Communist (but increasingly market oriented) government, it is important to understand how traders in Chinese markets in this process of transition behave.

Our paper concentrates on the effect of rumor clarification as well as the rumors themselves; this is quite different from previous research that focuses solely on rumors or rumor clarifications. The efficient market hypothesis (EMH) suggests that stock prices instantaneously reflect changes in fundamentals. Accordingly, we expect to find explicit evidence that when rumors turn out to be false, stock prices plummet right after the announcement. However, applying the EMH to investigate 
investors' behaviors in different market conditions, we hypothesize that market conditions matter when an investor responds to rumor clarification events.

\section{LITERATURE REVIEW}

The important influence of rumors and their dissemination on companies has attracted the attention of researchers and managers (Pittel, 1987; Kimmel, 2013; Kostka, Oswald and Wattenhofer, 2008), and the most direct response to this effect is the abnormal fluctuations in the stock price of the company (Başci, Özyildirim and Aydoğan, 1996). Financial markets have always had a flair for rumors, because on the trading floor all action is based on news. Knowing more than other market participants can lead to money profits. The traders may gamble if they believe the rumor reflects the truth, but even if it's not the case it can lead to financial consequences. Rumors in financial markets are seen as a substitute for news. News in financial markets is absolutely critical. Therefore, in the absence of news something is simply invented. In a tense, stressful working atmosphere, all traders operate with high-powered antennas. Investors' concerns about asymmetric information can lead to stress and anxiety (Tetlock, 2010). In these situations, they need to confirm the authenticity of news and investment strategy of others. Asymmetric information is often accompanied by speculation in securities market and what followed is the formation a classical form of rumor evolvement, namely rumors spread. As a result, the stock price fluctuates abnormally due to the different information of each stock holder.

Through the research method of the questionnaire, Schindler found that rumors are very different with information in financial market (Schindler, 2007). 1) Rumors are good for short-term trading. In the survey, more than $80 \%$ of the respondents indicate the existence of rumors will be considered in their investment decisions but it's different with verified information. Their explanation is that rumors are usually short-lived and therefore are traded on for much shorter time spans than information. 2) The degree of truth is the only uncertain variable with rumors. The participant's opinion is clear. $70 \%$ of the respondents indicate "in comparison to information one simply doesn't know if the rumor is going to be true." The answers with the next lower percentages are "there is no difference" with $9 \%$ and "they have nothing in common" with $8 \%$. This difference in attitude towards rumors forms different securities investment decisions.

In the face of rumors, companies often issue clarification announcements to deal with them. However, there are few studies on the clarification of the rumors at present and it is necessary to study the clarification effect of the clarification announcement. The research on the effect of rumor clarification is mainly focused on the methods of psychological experiments. The study of Bordia and DiFonzo's provided some support for the effectiveness of denials with strong arguments and an anxiety-alleviating tone in reducing rumor-related belief and anxiety. The effects of denial wording and source credibility were visible for participants who perceived high personal relevance of the topic (Bordia et al., 2005). At the same time, effect of source honesty and appropriateness on effectiveness of rumor denial was tested. When the source was perceived as high on honesty, the denial was more successful in reducing belief and anxiety associated with the rumor. Honesty and appropriateness had an additive effect, such that the denial was most successful in reducing belief when the source was perceived as high on both honesty and appropriateness (Bordia, DiFonzo and Schulz, 2000). Koller's research suggesting that with knowledge of the initial rumor the positive advertising strategy is superior to the rebuttal strategy in lowering subjects' susceptibility (Koller, 1992). Tybout and Calder show that a positive way of communicating with a company can better clarify the rumor than the direct negation of the rumor (Tybout, Calder and Sternthal, 1981).

Through the analysis of the current literature, we find that there are some shortcomings in the existing research. On one hand, relevant researches on rumors and rumor clarifications in the financial market are carried out separately and our research extends the scope of the established literature by examining the influence of rumor and rumor clarification on stock market during the 2015-2017. On 
the other hand, there are very few studies on the developing countries which have very big difference with developed countries in financial market environment such as traders, competition, culture and education, and all this can affect the mechanism of information value creation. As the largest developing country in the world, the market value of China's listed companies has leaped into the second place in the world, which has an important impact on the world economy. At the same time, there are few researches on the impact of rumors on stock price performance with Chinese companies.

\section{SAMPLE SELECTION PROCEDURE AND STATISTICAL METHODOLOGY}

\subsection{Sample Selection Procedure and Data Description}

The objective of this study is to analyze the stock price behavior and the impact of rumor and rumor clarification announced by firms on the corporate value. To accomplish this objective, we searched the wind database which is a leading financial company provides financial data, information and software services in China over the three-year period from 2015 to 2017, for news articles about firms announcing to clarify rumors. After searched the announcement module of Shanghai and Shenzhen listed companies, we obtained 918 rumor clarification announcements in total, including main board listed company, small and medium board listed company and growth enterprises market listed company. The data include securities code; securities name; the date of the rumor appear; the character of the rumor (negative/positive/neutral); the day of rumor clarification from firms and the specific content of the announcement.

After we got the 918 rumor clarification announcements, we checked the stock trading of this listed companies correspond to the announcements and eliminated some of the data which is not conforming to conditions. On one hand, we excluded the company data that has a particularly short listing time in the market. For example, Huida Weiyu (stock code: 603385) was first traded on the Shanghai Stock Exchange on April 5, 2017 and only after 12 days later, namely on April 17, 2017, Huida Weiyu released an announcement to clarify its rumor. Because of the significant premium effect (Chen, Firth and Kim 2004; Schenone 2004) of short time-to-market equities, we excluded this portion of the data to avoid affecting normal estimates. On the other hand, we excluded the announcements data that the company's stock is in a state of suspension when the corporate announces its clarification announcement. For example, LeTV (stock code: 300104 ) suspended more than 9 months from April 17, 2017 to January 24, 2018 and during this time, the rumor clarification announcement data have been removed released from LeTV. At last, 832 qualified announcement samples were screened out, including 463 negative rumors, 104 positive rumors and 265 neutral rumors. The distribution of 832 rumor announcement data over time is shown in Table 1.

According to the nature of the key lexicon and rumor of Wind database, it divides the rumors into positive, negative and neutral rumors. The key lexicon of positive rumors includes more profitable, turn loss into profit, signed orders, reorganized assets, be "backdoor" listed, research and development of new technology, get more markets, build a new factory, introduction of strategic investors, overall listing, acquisition of assets and asset injection etc. The key lexicon of negative

Table 1. Distribution of rumor data over time

\begin{tabular}{|l|l|l|l|l|}
\hline \multicolumn{1}{|c|}{ Year } & \multicolumn{1}{c|}{ Negative } & \multicolumn{1}{c|}{ Positive } & \multicolumn{1}{c|}{ Neutral } & \multicolumn{1}{c|}{ Full Sample } \\
\hline 2017 & 175 & 45 & 107 & 327 \\
\hline 2016 & 128 & 27 & 89 & 244 \\
\hline 2015 & 160 & 32 & 69 & 261 \\
\hline Total & 463 & 104 & 265 & 832 \\
\hline
\end{tabular}


rumors includes violation, manipulation, illegal, false, false statement, inflated, fraud, cheat, forgery, accept bribes, bribe, corruption, invade and occupy, breach of privilege, loss of state assets, smuggling, misappropriation of funds, embezzle public funds, commit a crime, tax evasion, detain, take into custody, arrest, pass a sentence, concealment of important matters, misleading statement, insider dealing and stripped of Party membership and expelled from public office etc. The database will classify it as a neutral rumor that cannot determine whether rumors will have a positive or negative impact on the market. For example, the rumor of replacing members of the board of directors by the shareholders' meeting of the company will be a neutral rumor.

As shown in Table 1, the number of negative rumors of Listed Companies in China is much more than that of positive rumors from 2015 to 2017. Because our rumors data come from the rumor clarification announcements of listed companies, this situation may be due to the fact that listed companies are more active in clearing negative rumors than positive rumors.

\subsection{Statistical Methodology}

In this research, we use event-analysis methods which are commonly employed in the accounting and finance to study the impact of rumor and official clarification announcements on common stock prices over the period 2015-2017. The event of interested in our study is the announcement of a rumor clarification by a company. According to financial theory, an announcement with new information will cause changes in the financial market for showing the attitude of investors. By comparing the normal returns of securities and the abnormal returns after events, we can calculate the impact of events on stock market using event analysis.

We assume that daily common stock returns are described by the market model, which is based on the capital asset pricing model (CAPM) (Elton and Gruber, 1997) which is the most widely used method to estimate the returns on a firm's stock. The market model is specified as follows:

$$
R_{i t}=\alpha_{i}+\beta_{i} R_{m t}+\delta_{i t}
$$

where:

$R_{i t}=$ rate of return for firm $i$ on day $t$

$R_{m t}=$ rate of return on the market portfolio on day $t$

$\alpha_{i}, \beta_{i}=$ parameters to be evaluated for firm $i$

$\delta_{i t}=$ random perturbation term for firm $i$ on day $t$

Each firm in the 832 samples is estimated with capital asset pricing model using 200 daily returns which is from the wind financial database. The announcement day defined as day 0 and the day before announcement day is day -1 and so on. $R_{m t}$ is market rate of return and it can be replaced by capitalization-weighted stock market index (CSI 300 Index) designed to replicate the performance of top 300 stocks traded in the Shanghai and Shenzhen stock exchanges. The abnormal return (AR and also called excess returns) for stock of company $i$ on event day $t$ are computed as the Formula (2):

$$
\left.A R_{\mathrm{it}}=R_{\mathrm{it}}-\bar{\alpha}_{i}+\bar{\beta}_{i} R_{m t}\right)
$$

where:

$\bar{\alpha}_{i}, \bar{\beta}_{i}=$ CAPM model parameters of company $i$ 
The cumulative abnormal return in the event period of day $x$ and day $y$, is computed as:

$\operatorname{CAR}(x, y)=\sum_{i=x}^{y} A R_{i, t}$

\section{THE IMPACT OF RUMOR ON STOCK PRICE}

\subsection{Research Hypothesis}

Rumors do not just fill up time around the water fountain. They can drain productivity, reduce profits, create stress in the workplace, or sully a company's image (DiFonzo, Bordia and Rosnow, 1994). Some rumors tear at a company's credibility, particularly the negative rumors, with both personnel and customers. Others have catapulted firms into financial disaster. According to the research of Schindler, when there is a rumor appeared, most people will wait and see, and they follow other people's rumor attitude to adjust the investment strategy (Schindler, 2007). When there is positive rumor, some investors expect the stock to go up and buy. As a result, a large number of investors will follow up and form a herd effect, causing the stock price to rise, thus giving these investors positive stock abnormal returns. On the contrary, when there is negative rumor, some investors expect that the stock will fall and sell. As a result, a large number of investors will sell it subsequently, causing the stock price to fall so that these investors will obtain an abnormal negative return on the stock. The emergence of neutral rumors without special information will not affect investors' investment behavior. Based on the above analysis, this study proposes the following assumptions:

H1a: The negative rumor will have a negative impact on the value of the corporation.

H1b: The positive rumor will have a positive impact on the value of the corporation.

H1c: The neutral rumor will show weak or non-existent impact on the value of the corporation.

\subsection{Research Results}

What this section shows is the results of the influence of rumors on the firm's stock price performance with different types of rumor nature. We illustrate the two aspects of the descriptive statistical results of the abnormal returns and the results of $\mathrm{Z}$ test respectively.

A time line in this part of research is represented in the Figure 1. Selection of the length of event period and estimation period is based on previous event studies and institutional factors. Accordingly, this study used event period between the rumors appear day and the day before the clarification day.

In Table 2, notice that for rumors of different nature of cumulative excess returns is all significantly different from zero between the event periods. In different type of rumors, both positive and neutral types are significantly different from zero with positive cumulative abnormal return. Specifically, the average cumulative excess returns in the event periods for the positive rumor sample and neutral rumor sample is $2.08 \%$ and $1.21 \%$, respectively. In other words, the positive rumors induce greater reactions in stock market than neutral rumor. From the result above, we can see that the research hypothesis

Figure 1. Estimation and event period

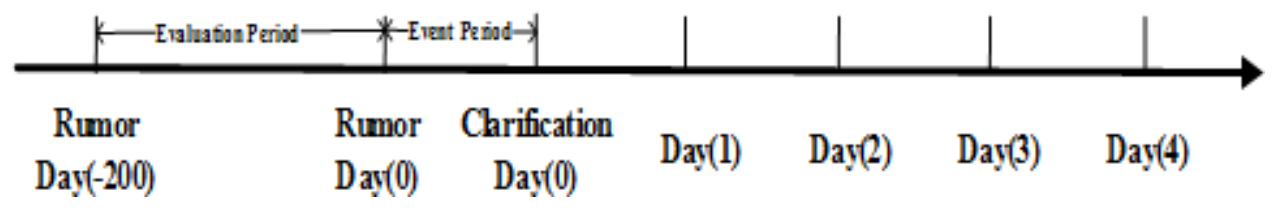


Table 2. Cumulative abnormal returns for different rumor category

\begin{tabular}{|l|l|l|}
\hline \multicolumn{1}{|c|}{ Rumor Nature $^{\mathbf{b}}$} & Cumulative Abnormal Return (\%) & \multicolumn{1}{c|}{ Z-Value $^{\mathbf{a}}$} \\
\hline Negative Rumor (463) & -1.09 & $-5.34 * * *$ \\
\hline Positive Rumor (104) & 2.08 & $4.83^{* * *}$ \\
\hline Neutral Rumor (265) & 1.21 & $4.47 * * *$ \\
\hline
\end{tabular}

aZ-statistic is under the null hypothesis that the average excess return is zero.

${ }^{b}$ Sample sizes are in parentheses

${ }^{* *} p<0.05,{ }^{* * *} p<0.01$

$\mathrm{H} 1 \mathrm{~b}$ is supported, but not in the case of H1c. For the negative rumor sample, the cumulative excess return is significantly different from zero with -1.09 excess returns, which means that the hypothesis H1a passed the verification.

\section{THE IMPACT OF RUMOR CLARIFICATION ON STOCK PRICE}

\subsection{Research Hypothesis}

In recent years, the positive influence of news media on firm performance or corporate governance have received extensive attention of researchers (Dyck, Morse and Zingales, 2010; Dyck, Volchkova and Zingales, 2008; Joe, Louis and Robinson, 2009; Peress, 2014), such as improving the effectiveness of financial markets (Tetlock, 2007), or reducing information asymmetry between investors and companies (Bushee et al., 2010; Fang and Peress, 2009; Peress, 2014). At the same time, shareholders of firms expect to get the company information form news media which is easy to acquire, and the other useful information is difficult to get on themselves. In the developing financial market of China, the information asymmetry is particularly large between companies and investors and this situation always causing manipulation of stock prices and insider trading (Chakravarty, Sarkar and Wu, 1998). In order to eliminate the impact of such information asymmetry caused by rumors on enterprises, many firms do this by releasing clarification announcements.

When the listed company issued a clarification announcement for positive rumors, the information that supported the price rise did not get the approval of the company, which to a certain extent undermined investor confidence in the value of the company. And investors who are holding rumored corporate' stock have a stronger incentive to evaluate the truth of the rumors and believe the company has denied positive rumors causing a risk of a fall in stock prices. According to the disposition effect theory (Shefrin and Statman, 1985; Weber and Camerer, 1998), investors are risk-averse when they are profitable. That is to say, if the investor continues to hold the shares, the subsequent decline of stock price will reduce the gains already obtained, resulting in a loss of revenue. If the investors choose to sell the stock, they can get a certain stock return that has been accumulated. According to the deterministic effect theory (Sontag, 2013) in prospect theory, investors that received abnormal returns choose to sell their shares between selling off the stock for a certain earnings and continuing to hold the stock, leading to a loss of return. Since investors' expectation of profit-making in selling stocks is the best choice for rationality, investors will inevitably sell a large number of shares, resulting in a drop in stock price and a positive cumulative abnormal return. For the neutral rumors that do not have a special information impact on stock price, cumulative abnormal returns of stock due to herding effect will disappear as announcements of rumor clarifications are released. Based on the above analysis, this study proposes the following research hypotheses:

H2a: For the positive rumors, the announcement of clarification can eliminate the effects of rumors.

The positive cumulative abnormal returns after the announcement will disappear. 
H2b: For neutral rumors, the announcement of clarification can eliminate the effects of rumors. The cumulative abnormal returns after the announcement will disappear.

In recent years, unscrupulous behaviors of listed companies in China (such as oil spills in the Bohai Sea, melamine incidents, clenbuterol event, etc.) and by large shareholders between related party transactions and profit transfer, assets reorganization and other behaviors to damage the interests of small shareholders, causing a serious crisis of trust in listed companies. Negative information is more likely to attract investors' attention than positive information, and investors are more likely to incorporate negative information into decision-making and respond more strongly to negative information (Pfarrer, Pollock and Rindova, 2010). A large number of researches in cognitive psychology show that there is a widespread negative bias in individual decision-making. That is to say, compared with positive events, individuals will pay more attention to negative events and give them more weight in decision-making and evaluation (Rozin and Royzman, 2001). According to the theory of prospect, we know that investors are loss averse, that is, investors are more sensitive to the same pain (loss) than the same pleasures (gains). Therefore, for negative rumors, to avoid the pain caused by the loss, investors reacted to the company's negative rumors by making radical reactions, such as selling stocks in large quantities, resulting in a decrease in stock returns. When the listed company tries to clarify the negative rumors by clarifying the announcement, investors are untrustworthy about the company's disclosed information (Jia, Ruan and Zhang, 2017). They even think that the listed company is hiding the real information, causing investors not responded to the clarification announcement. Based on the above analysis, this study proposes the following research hypotheses.

H2c: For negative rumors, the announcement of clarification cannot eliminate the effects of rumors.

The cumulative abnormal returns after the announcement will continue to decline.

\subsection{Research Results for the Full Example}

It is interesting to examine the rumor clarification effects of full negative, positive and neutral rumors example in listed companies in China using more recent data. What this section shows is the results of the full example of rumor clarification announcement on the company's stock price performance.

We can see in Table 3, for the full example of negative rumor, positive rumor and neutral rumor, the cumulative abnormal returns after the rumor clarification announcements show different features

Table 3. Cumulative abnormal returns after rumor clarification over time

\begin{tabular}{|l|l|l|l|l|l|l|}
\hline \multirow{2}{*}{$\begin{array}{c}\text { Cumulative Abnormal } \\
\text { Returns }\end{array}$} & \multicolumn{2}{|c|}{ Negative Rumor } & \multicolumn{2}{c|}{ Positive Rumor } & \multicolumn{3}{c|}{ Neutral Rumor } \\
\cline { 2 - 7 } & \multicolumn{1}{|c|}{ Mean } & \multicolumn{1}{|c|}{ Z-Value } & \multicolumn{1}{c|}{ Mean } & Z-Value & \multicolumn{1}{c|}{ Mean } & \multicolumn{1}{c|}{ Z-Value } \\
\hline CAR[T,D+0] & $\begin{array}{l}-1.252 \\
(463)\end{array}$ & $-4.36^{*} * *$ & $\begin{array}{l}2.605 \\
(104)\end{array}$ & $4.28 * * *$ & $\begin{array}{l}1.294 \\
(265)\end{array}$ & $3.39 * * *$ \\
\hline CAR[T,D+1] & $\begin{array}{l}-1.586 \\
(463)\end{array}$ & $-4.74 * * *$ & $\begin{array}{l}2.480 \\
(104)\end{array}$ & $3.50^{* * *}$ & $\begin{array}{l}1.024 \\
(265)\end{array}$ & $2.30^{* * *}$ \\
\hline CAR[T,D+2] & $\begin{array}{l}-1.697 \\
(463)\end{array}$ & $-4.59 * * *$ & $\begin{array}{l}2.878 \\
(104)\end{array}$ & $3.68 * * *$ & $\begin{array}{l}0.765 \\
(265)\end{array}$ & 1.56 \\
\hline CAR[T,D+3] & $\begin{array}{l}-1.929 \\
(463)\end{array}$ & $-4.71 * * *$ & $\begin{array}{l}2.860 \\
(104)\end{array}$ & $3.30^{* * *}$ & $\begin{array}{l}0.544 \\
(265)\end{array}$ & 1.00 \\
\hline CAR[T,D+4] & $\begin{array}{l}-1.968 \\
(463)\end{array}$ & $-4.25 * * *$ & $\begin{array}{l}2.578 \\
(104)\end{array}$ & $2.95 * * *$ & $\begin{array}{l}0.372 \\
(265)\end{array}$ & 0.60 \\
\hline
\end{tabular}

aZ-statistic is under the null hypothesis that the average excess return is zero.

${ }^{\mathrm{D}} \mathrm{T}$ is the rumor day and $\mathrm{D}$ is the rumor clarification day.

${ }^{*} p<0.1,{ }^{* *} p<0.05,{ }^{* * *} p<0.01$ 
over time. The clarifications for negative rumors have no effect and the stock's earnings continue to deteriorate with more and more significant features. That is to say, the $\mathrm{H} 2 \mathrm{c}$ is supported. The mean value of CAR after positive rumor clarification remains very small change and the positive cumulative abnormal returns do not rise after the clarification announcement anymore ${ }^{1}$, which means that the hypothesis $\mathrm{H} 2 \mathrm{a}$ is supported. When it comes to the neutral rumor example, the result shows that after the clarification the mean value of positive CAR keep a downward trend and at the same time, the $\mathrm{Z}$-value of the CAR is also falling, and from significant to not significant. The $\mathrm{H} 2 \mathrm{~b}$ is supported as well. From Figure 2, we can see the trend of mean value of CAR in different types of rumor examples after the clarification day more intuitively.

Through the analysis of the full samples of rumor clarification in the article above, we have obtained some research results. However, due to the lack of sample companies that did not clarify the rumors, there was no reference to the control group. In the real market environment, almost all listed companies will have rumors, and they will clarify some of the rumors, resulting in this research is difficult to really get a company sample that has rumors but not release announcement of rumor clarification. However, in the research data collating process, we found there are different time lags between the time for appearing of listed company rumors and the time for the publication of clarifications for rumors. This discovery provides the possibility for the construction of a control group for this study.

We divide the full samples into three groups according to the difference of the time of the rumor clarification: $\mathrm{C} 1$, which means that the company issues the clarification announcement within one day after the rumor day; $\mathrm{C} 2$, which means that the company releases the clarification announcement on the second day of rumor day and C3, which means that the company issues the announcement more than two days after the rumor day. Through this way of setting up the control group, we examine the sample differences at different clarification times.

\subsection{Research Results for the Negative Rumor Clarification Example}

In this part, we show the effect of negative rumor clarification on the stock price in different clarification time intervals after the rumor. We illustrate the two aspects of the descriptive statistical results of the abnormal returns and the results of $\mathrm{Z}$ test respectively.

Figure 2. CAR after rumor day for full example over time

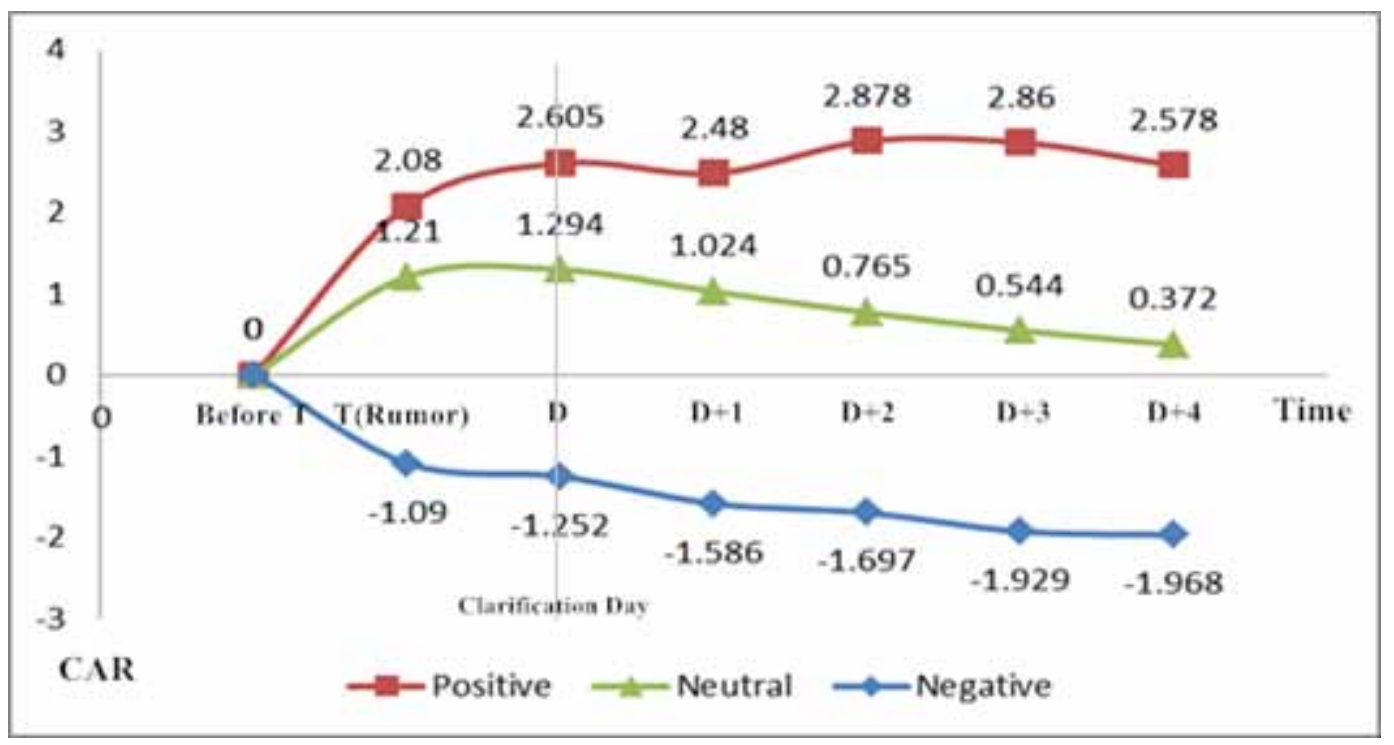


Table 4 reports the mean value and $\mathrm{Z}$ value of the CAR of different negative rumor samples. From the table, we can know that after the negative rumor clarification day, the mean value of CAR for three groups are all show a trend of gradual decline and this phenomenon also confirms the conclusions of the study above. However, we can clearly find the differences between different groups over time. For every day, after the negative rumor day, the negative mean value of CAR for companies issuing announcement within one day $(\mathrm{C} 1)$ is greater than that of the second day $(\mathrm{C} 2)$, which is greater than that of more than two days (C3). That is to say, after the rumors came up, releasing clarification announcements earlier than clarification announcements late could mitigate the impact on the company's shares. At the same time, the $\mathrm{Z}$ values of total excess returns in each groups are turn to not significantly different from zero from significantly at the beginning. From Figure 3 , we can more intuitively see the trend of CAR changes for each group over time.

\subsection{Research Results for the Positive Rumor Clarification Example}

What this section shows is the results of the influence to market value after the rumor day for the positive rumor in different announcement times. We illustrate the two aspects of the descriptive statistical results of the abnormal returns and the results of $\mathrm{Z}$ test respectively.

Table 4. Cumulative abnormal returns after rumor day for negative rumor

\begin{tabular}{|c|c|c|c|c|c|c|c|c|c|c|c|c|}
\hline \multirow{2}{*}{ CAR } & \multicolumn{2}{|c|}{ Rumor Day(0) } & \multicolumn{2}{|c|}{$\mathrm{D}(\mathbf{0 , 1})$} & \multicolumn{2}{|c|}{$\mathrm{D}(\mathbf{0 , 2 )}$} & \multicolumn{2}{|c|}{$\mathrm{D}(\mathbf{0 , 3})$} & \multicolumn{2}{|c|}{$\mathrm{D}(\mathbf{0 , 4 )}$} & \multicolumn{2}{|c|}{$\mathrm{D}(\mathbf{0 , 5 )}$} \\
\hline & Mean & Z-Value & Mean & Z-Value & Mean & Z-Value & Mean & Z-Value & Mean & Z-Value & Mean & Z-Value \\
\hline $\mathrm{C} 1$ & \multirow{3}{*}{$\begin{array}{l}-0.932 \\
(463)\end{array}$} & \multirow{3}{*}{$-4.35 * * *$} & $\begin{array}{l}-0.667 \\
(295)\end{array}$ & $-2.07 * *$ & $\begin{array}{l}-1.053 \\
(295)\end{array}$ & $-2.64 * * *$ & $\begin{array}{l}-1.404 \\
(295)\end{array}$ & $-2.25 * *$ & $\begin{array}{l}-1.608 \\
(295)\end{array}$ & $-2.28 * *$ & $\begin{array}{l}-1.555 \\
(295)\end{array}$ & -1.27 \\
\hline $\mathrm{C} 2$ & & & \multirow{2}{*}{$\begin{array}{l}-2.017 \\
(168)\end{array}$} & \multirow{2}{*}{$-3.68 * * *$} & $\begin{array}{l}-1.200 \\
(75)\end{array}$ & $-1.64 *$ & $\begin{array}{l}-1.715 \\
(75)\end{array}$ & $-1.86^{*}$ & $\begin{array}{l}-1.763 \\
(75)\end{array}$ & -1.09 & $\begin{array}{l}-1.772 \\
(75)\end{array}$ & -0.54 \\
\hline $\mathrm{C} 3$ & & & & & $\begin{array}{l}-2.868 \\
(93)\end{array}$ & $-3.42 * * *$ & $\begin{array}{l}-2.388 \\
(93)\end{array}$ & $-2.32 * *$ & $\begin{array}{l}-2.551 \\
(93)\end{array}$ & $-1.96 * *$ & $\begin{array}{l}-2.515 \\
(93)\end{array}$ & -1.03 \\
\hline
\end{tabular}

aZ-statistic is under the null hypothesis that the average excess return is zero.

'Sample sizes are in parentheses.

${ }^{*} p<0.1,{ }^{* *} p<0.05,{ }^{* * *} p<0.01$

Figure 3. CAR after rumor day for negative example over time

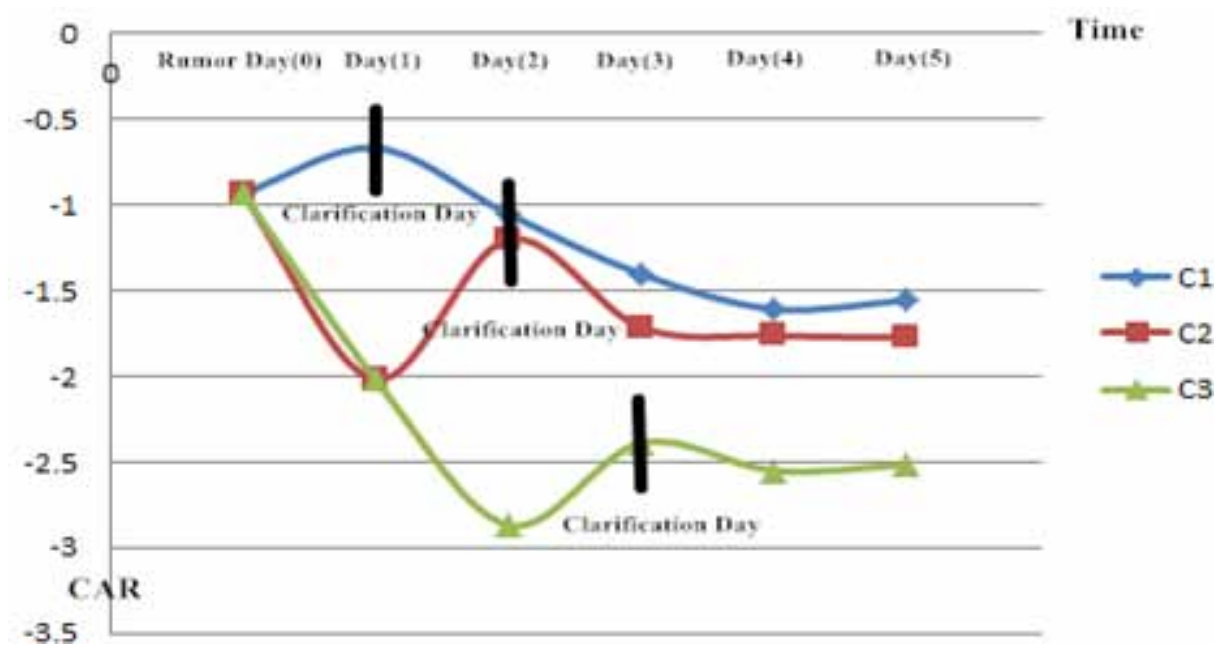


In Table 5, we notice that most companies, more than $70 \%$, chose to issue a clarification announcement within one day, among the companies that chose to clarify a positive rumor. Specifically, companies which chose to issue the clarification announcement in the second day and more than two days is $16.35 \%$ and $12.50 \%$ in our research sample, respectively.

At the same time, we can see the $\mathrm{C} 1$ sample of total excess returns are all significantly different from zero each day after the rumor day and the mean value of CAR shows small change after the clarification day, namely the second day. In the type of $\mathrm{C} 2$ and $\mathrm{C} 3$, which clarification time is later than $\mathrm{C} 1$, the mean values of CAR continue to rise until the clarification day and the mean value of total average excess returns exceeded 5\% in the sample of C2 and C3 in the end. In other words, choosing a quick clarification of positive rumors can reduce abnormal fluctuations in stock prices. From Figure 4, we can see the results more intuitively.

\subsection{Research Results for the Neutral Rumor Clarification Example}

What this section shows is the results of the influence to market value after the rumor day for the neutral rumor in different announcement times. We illustrate the two aspects of the descriptive statistical results of the abnormal returns and the results of $\mathrm{Z}$ test respectively.

From Table 6, we know that for China listed companies, clarifying the neutral rumors can eliminate the impact of rumors on the stock price of the company. We can see from all groups (C1)

Table 5. Cumulative abnormal returns after rumor day for positive rumor

\begin{tabular}{|c|c|c|c|c|c|c|c|c|c|c|c|c|}
\hline \multirow{2}{*}{ CAR } & \multicolumn{2}{|c|}{ Rumor Day(0) } & \multicolumn{2}{|c|}{$D(0,1)$} & \multicolumn{2}{|c|}{$\mathrm{D}(0,2)$} & \multicolumn{2}{|c|}{$D(0,3)$} & \multicolumn{2}{|c|}{$D(0,4)$} & \multicolumn{2}{|c|}{$D(0,5)$} \\
\hline & Mean & Z-Value & Mean & Z-Value & Mean & Z-Value & Mean & Z-Value & Mean & Z-Value & Mean & Z-Value \\
\hline $\mathrm{C} 1$ & \multirow{3}{*}{$\begin{array}{l}2.283 \\
(104)\end{array}$} & \multirow{3}{*}{$4.11 * * *$} & $\begin{array}{l}3.089 \\
(74)\end{array}$ & $4.19^{* * *}$ & $\begin{array}{l}2.970 \\
(74)\end{array}$ & $4.03 * * *$ & $\begin{array}{l}3.263 \\
(74)\end{array}$ & $3.94 * * *$ & $\begin{array}{l}3.264 \\
(74)\end{array}$ & $3.46^{* * * *}$ & $\begin{array}{l}3.238 \\
(74)\end{array}$ & $3.26 * * *$ \\
\hline $\mathrm{C} 2$ & & & \multirow{2}{*}{$\begin{array}{l}2.737 \\
(30)\end{array}$} & \multirow{2}{*}{$2.02 * *$} & $\begin{array}{l}4.650 \\
(17)\end{array}$ & $1.64^{*}$ & $\begin{array}{l}5.1452 \\
(17)\end{array}$ & $1.78^{*}$ & $\begin{array}{l}5.070 \\
(17)\end{array}$ & $2.02 * *$ & $\begin{array}{l}5.269 \\
(17)\end{array}$ & $1.73^{*}$ \\
\hline $\mathrm{C} 3$ & & & & & $\begin{array}{l}4.308 \\
(13)\end{array}$ & $1.73^{*}$ & $\begin{array}{l}4.700 \\
(13)\end{array}$ & 1.42 & $\begin{array}{l}4.738 \\
(13)\end{array}$ & $1.65^{*}$ & $\begin{array}{l}5.621 \\
(13)\end{array}$ & 1.35 \\
\hline
\end{tabular}

aZ-statistic is under the null hypothesis that the average excess return is zero.

${ }^{b}$ Sample sizes are in parentheses.

${ }^{*} p<0.1,{ }^{* *} p<0.05,{ }^{* * *} p<0.01$

Figure 4. CAR after rumor day for positive example over time

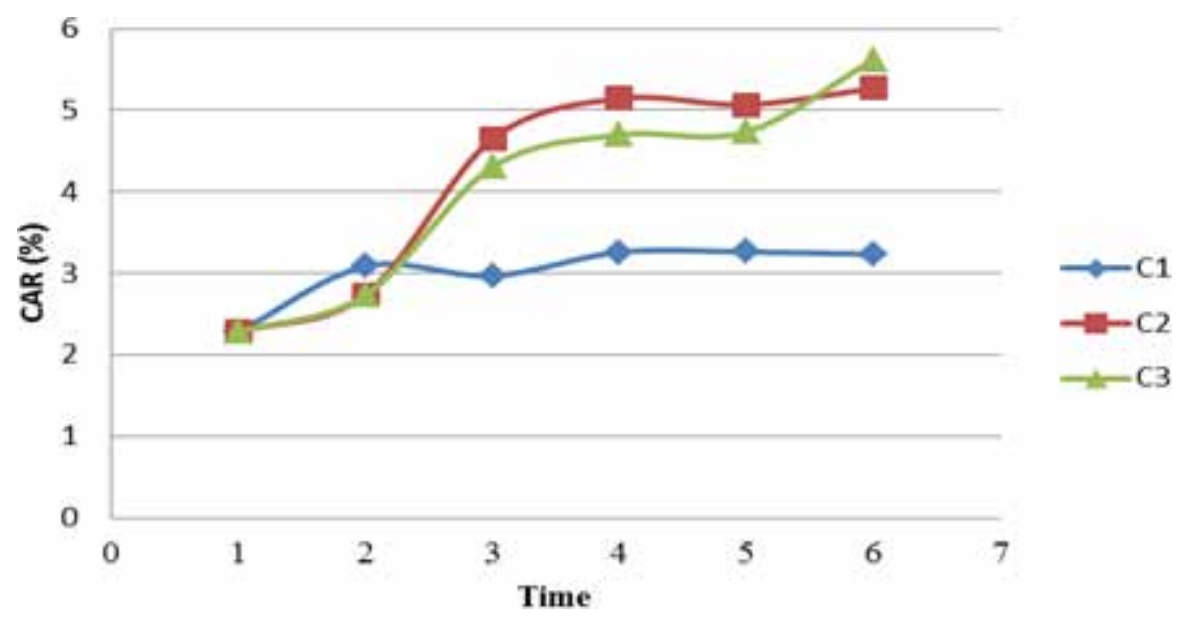


Table 6. Cumulative abnormal returns after rumor day for neutral rumor

\begin{tabular}{|c|c|c|c|c|c|c|c|c|c|c|c|c|}
\hline \multirow{2}{*}{ CAR } & \multicolumn{2}{|c|}{ Rumor Day(0) } & \multicolumn{2}{|c|}{$\mathrm{D}(\mathbf{0 , 1})$} & \multicolumn{2}{|c|}{$\mathrm{D}(\mathbf{0 , 2})$} & \multicolumn{2}{|c|}{$\mathrm{D}(\mathbf{0 , 3})$} & \multicolumn{2}{|c|}{$\mathrm{D}(\mathbf{0 , 4})$} & \multicolumn{2}{|c|}{$\mathrm{D}(\mathbf{0 , 5})$} \\
\hline & Mean & Z-Value & Mean & Z-Value & Mean & Z-Value & Mean & Z-Value & Mean & Z-Value & Mean & Z-Value \\
\hline $\mathrm{C} 1$ & \multirow{3}{*}{$\begin{array}{l}1.302 \\
(265)\end{array}$} & \multirow{3}{*}{$4.66^{* * * *}$} & $\begin{array}{l}1.262 \\
(197)\end{array}$ & $3.62 * * *$ & $\begin{array}{l}1.153 \\
(197)\end{array}$ & $2.35^{* * *}$ & $\begin{array}{l}0.937 \\
(197)\end{array}$ & $1.82 *$ & $\begin{array}{l}0.692 \\
(197)\end{array}$ & 1.18 & $\begin{array}{l}0.224 \\
(197)\end{array}$ & 0.35 \\
\hline $\mathrm{C} 2$ & & & \multirow{2}{*}{$\begin{array}{l}1.546 \\
(68)\end{array}$} & \multirow{2}{*}{$1.9,4^{*}$} & $\begin{array}{l}1.214 \\
(51)\end{array}$ & $2.33^{* * *}$ & $\begin{array}{l}1.081 \\
(51)\end{array}$ & $1.89^{*}$ & $\begin{array}{l}1.041 \\
(51)\end{array}$ & 1.55 & $\begin{array}{l}0.549 \\
(51)\end{array}$ & 1.03 \\
\hline $\mathrm{C} 3$ & & & & & $\begin{array}{l}1.032 \\
(17)\end{array}$ & $1.91^{*}$ & $\begin{array}{l}0.967 \\
(17)\end{array}$ & $1.87^{*}$ & $\begin{array}{l}0.314 \\
(17)\end{array}$ & $1.66 *$ & $\begin{array}{l}0.495 \\
(17)\end{array}$ & 1.32 \\
\hline
\end{tabular}

aZ-statistic is under the null hypothesis that the average excess return is zero.

${ }^{b}$ Sample sizes are in parentheses.

${ }^{*} p<0.1,{ }^{* *} p<0.05,{ }^{* * *} p<0.01$

C2lC3) that the overall mean value of average excess returns is decreasing after the neutral rumor clarification announcements and the Z-values of CAR in three groups are not significant in the end of our research time. However, when the clarification time for the rumors was different, we did not find any regularity in our analysis. In other words, there is no significant difference in the clarification effect of choosing neutral rumors at different times. In our research sample, the companies choosing to clarify the rumors within one day, in the second day and more than two days are $74.34 \%, 19.25 \%$ and $6.52 \%$, respectively. Figure 5 of CAR after rumor day for neutral example over time is as follows.

\section{CONCLUSION AND LIMITATIONS}

This study has examined the responses of stock price to rumors and official announcements of rumor clarification with China Listed Companies spanning the period of 2015-2017. We also investigated whether, in addition to the types of different rumors and the types of rumor clarifications, this information will increase the market value of the firm and the effect changes over time. In analyzing the full sample of 832 rumors, the results indicate positive effects of price with $2.08 \%$ and $1.21 \%$ average excess earnings for positive rumors and neutral rumors in the event period, as well as $-1.09 \%$ cumulative abnormal returns for the negative rumor sample. After the rumor clarification of firms, we find positive effect for the positive and neutral rumors, but not in the case of negative rumors.

Figure 5. CAR after rumor day for neutral example over time

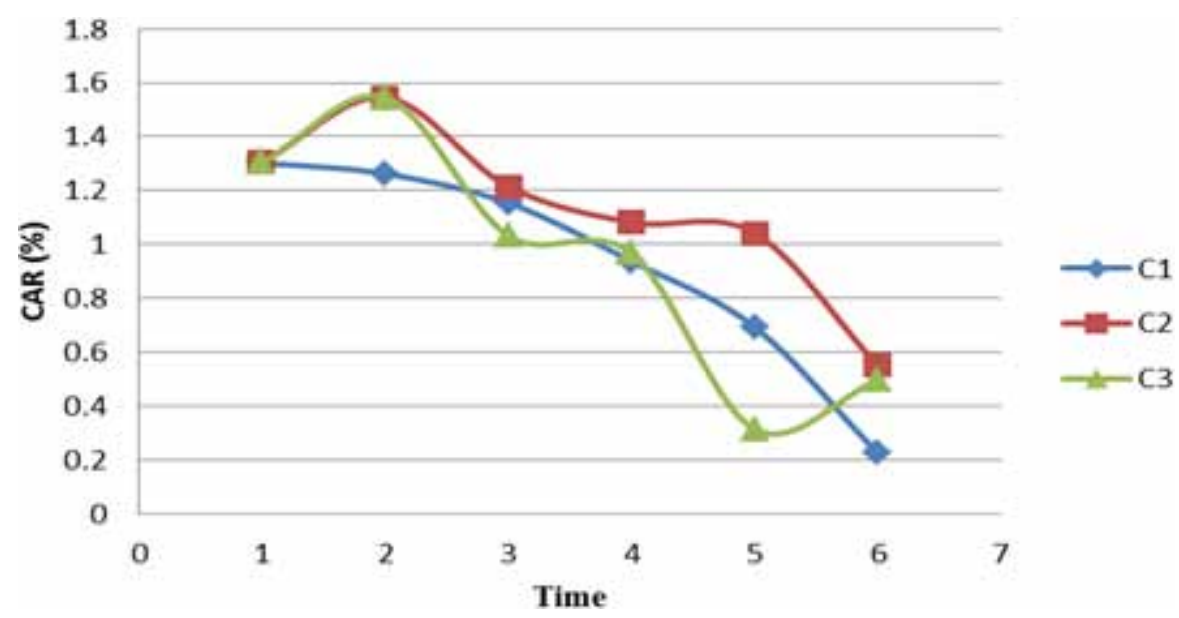


Consistently, we find that the sooner a clarification announcement is issued, the more likely it is to reduce the abnormal volatility of the stock price for positive and negative rumor sample, but not applicable for neutral sample.

Akin to other studies, this study is not without limitations. First, we only collect limited sample for our study. There is no large-sample about the rumor information data set in China, so this study was compelled to use limited sample data from China, hence this could lead to errors of too early generalization. Second, the lack of company samples that did not clarify the rumors led to the absence of a more intuitive control group.

Future research could pursue several other directions. First, it could explore the impact of clarification announcement on firms when the rumors come from different sources, such as whether the rumors come from authoritative media. Moreover, future studies could provide advises to firms facing the rumors and could provide evidence when and how to clarify the rumors will have a best effect.

\section{ACKNOWLEDGMENT}

This work was supported by the National Natural Science Foundation of China under Grant No.71531013; 71490720; 71401047. Xiangbin Yan is a corresponding author on this paper. 


\section{REFERENCES}

Başci, E., Özyildirim, S., \& Aydoğan, K. (1996). A note on price-volume dynamics in an emerging stock market. Journal of Banking \& Finance, 20(2), 389-400. doi:10.1016/0378-4266(95)00003-8

Below, S. D., \& Johnson, K. H. (1996). An analysis of shareholder reaction to dividend announcements in bull and bear markets. Journal of Financial and Strategic Decisions, 9(3), 15-26.

Bordia, P., DiFonzo, N., Haines, R., \& Chaseling, E. (2005). Rumors denials as persuasive messages: Effects of personal relevance, source, and message characteristics. Journal of Applied Social Psychology, 35(6), 1301-1331. doi:10.1111/j.1559-1816.2005.tb02172.x

Bordia, P., DiFonzo, N., \& Schulz, C. A. (2000). Source characteristics in denying rumors of organizational closure: Honesty is the best policy. Journal of Applied Social Psychology, 30(11), 2309-2321. doi:10.1111/j.1559-1816.2000.tb02438.x

Bushee, B. J., Core, J. E., Guay, W., \& Hamm, S. J. W. (2010). The role of the business press as an information intermediary. Journal of Accounting Research, 48(1), 1-19. doi:10.1111/j.1475-679X.2009.00357.x

Chakravarty, S., Sarkar, A., \& Wu, L. (1998). Information asymmetry, market segmentation and the pricing of cross-listed shares: Theory and evidence from Chinese A and B shares. Journal of International Financial Markets, Institutions and Money, 8(3-4), 325-356. doi:10.1016/S1042-4431(98)00041-9

Chen, G., Firth, M., \& Kim, J. B. (2004). IPO underpricing in China's new stock markets. Journal of Multinational Financial Management, 14(3), 283-302. doi:10.1016/j.mulfin.2003.07.007

DiFonzo, N., Bordia, P., \& Rosnow, R. L. (1994). Reining in rumors. Organizational Dynamics, 23(1), 47-62. doi:10.1016/0090-2616(94)90087-6

Docking, D. S., \& Koch, P. D. (2005). Sensitivity of investor reaction to market direction and volatility: Dividend change announcements. Journal of Financial Research, 28(1), 21-40. doi:10.1111/j.1475-6803.2005.00112.x

Dyck, A., Morse, A., \& Zingales, L. (2010). Who blows the whistle on corporate fraud? The Journal of Finance, 65(6), 2213-2253. doi:10.1111/j.1540-6261.2010.01614.x

Dyck, A., Volchkova, N., \& Zingales, L. (2008). The corporate governance role of the media: Evidence from Russia. The Journal of Finance, 63(3), 1093-1135. doi:10.1111/j.1540-6261.2008.01353.x

Elton, E. J., \& Gruber, M. J. (1997). Modern portfolio theory, 1950 to date. Journal of Banking \& Finance, 21(11), 1743-1759. doi:10.1016/S0378-4266(97)00048-4

Fang, L., \& Peress, J. (2009). Media coverage and the cross-section of stock returns. The Journal of Finance, 64(5), 2023-2052. doi:10.1111/j.1540-6261.2009.01493.x

Green, S. (2003). China's stock market eight myths and some reasons to be optimistic.

Jia, M., Ruan, H., \& Zhang, Z. (2017). How rumors fly. Journal of Business Research, 72, 33-45. doi:10.1016/j. jbusres.2016.11.010

Joe, J. R., Louis, H., \& Robinson, D. (2009). Managers' and investors' responses to media exposure of board ineffectiveness. Journal of Financial and Quantitative Analysis, 44(3), 579-605. doi:10.1017/S0022109009990044

Kapferer, J.-N. (1996). Gerüchte. Das älteste Massenmedium der Welt, Leipzig.

Kimmel, A. J. (2013). Rumors and rumor control: A manager's guide to understanding and combatting rumors. Routledge. doi:10.4324/9781410609502

Kiymaz, H. (2002). The stock market rumours and stock prices: A test of price pressure and size effect in an emerging market. Applied Financial Economics, 12(7), 469-474. doi:10.1080/09603100010005852

Koller, M. (1992). Rumor rebuttal in the marketplace. Journal of Economic Psychology, 13(1), $167-186$. doi:10.1016/0167-4870(92)90058-F

Kostka, J., Oswald, Y.A., \& Wattenhofer, R. (2008). Word of mouth: Rumor dissemination in social networks. 
Lee, J.-S., Kuo, C.-T., \& Yen, P.-H. (2011). Market states and initial returns: Evidence from Taiwanese IPOs. Emerging Markets Finance \& Trade, 47(2), 6-20. doi:10.2753/REE1540-496X470201

Lim, T. K., \& Kong, H. C. (2004). New evidence on price impact of analyst forecast revisions. International Review of Financial Analysis, 13(2), 161-190. doi:10.1016/j.irfa.2004.02.004

Mian, G. M., \& Sankaraguruswamy, S. 2008. Investor sentiment and stock market response to corporate news. National University of Singapore.

Peress, J. (2014). The media and the diffusion of information in financial markets: Evidence from newspaper strikes. The Journal of Finance, 69(5), 2007-2043. doi:10.1111/jofi.12179

Pfarrer, M. D., Pollock, T. G., \& Rindova, V. P. (2010). A tale of two assets: The effects of firm reputation and celebrity on earnings surprises and investors' reactions. Academy of Management Journal, 53(5), 1131-1152. doi:10.5465/amj.2010.54533222

Pittel, B. (1987). On spreading a rumor. SIAM Journal on Applied Mathematics, 47(1), $213-223$. doi: $10.1137 / 0147013$

Rozin, P., \& Royzman, E. B. (2001). Negativity bias, negativity dominance, and contagion. Personality and Social Psychology Review, 5(4), 296-320. doi:10.1207/S15327957PSPR0504_2

Schenone, C. (2004). The Effect of Banking Relationships on the Firm's IPO Underpricing. The Journal of Finance, 59(6), 2903-2958. doi:10.1111/j.1540-6261.2004.00720.x

Schindler, M. (2007). Rumors in financial markets. London, GB: John Wiley \& Sons, Ltd.

Schindler, M. P. (2003). Rumors in Financial Markets: Survey on how they evolve, spread and are traded on. Inst. for Empirical Research in Economics.

Shefrin, H., \& Statman, M. (1985). The disposition to sell winners too early and ride losers too long: Theory and evidence. The Journal of Finance, 40(3), 777-790. doi:10.1111/j.1540-6261.1985.tb05002.x

Sontag, E. D. (2013). Mathematical control theory: deterministic finite dimensional systems (Vol. 6). Springer Science \& Business Media.

Tetlock, P. C. (2007). Giving content to investor sentiment: The role of media in the stock market. The Journal of Finance, 62(3), 1139-1168. doi:10.1111/j.1540-6261.2007.01232.x

Tetlock, P. C. (2010). Does public financial news resolve asymmetric information? Review of Financial Studies, 23(9), 3520-3557. doi:10.1093/rfs/hhq052

Tybout, A. M., Calder, B. J., \& Sternthal, B. (1981). Using information processing theory to design marketing strategies. JMR, Journal of Marketing Research, 18(1), 73-79. doi:10.1177/002224378101800107

Van Bommel, J. (2003). Rumors. The Journal of Finance, 58(4), 1499-1520. doi:10.1111/1540-6261.00575

Weber, M., \& Camerer, C. F. (1998). The disposition effect in securities trading: An experimental analysis. Journal of Economic Behavior \& Organization, 33(2), 167-184. doi:10.1016/S0167-2681(97)00089-9

Wen, S., Jiang, J., Xiang, Y., Yu, S., Zhou, W., \& Jia, W. (2014). To shut them up or to clarify: Restraining the spread of rumors in online social networks. IEEE Transactions on Parallel and Distributed Systems, 25(12), 3306-3316. doi:10.1109/TPDS.2013.2297115

Yang, X., \& Luo, Y. (2014). Rumor Clarification and Stock Returns: Do Bull Markets Behave Differently from Bear Markets? Emerging Markets Finance \& Trade, 50(1), 197-209. doi:10.2753/REE1540-496X500111

\section{ENDNOTE}

After releasing a positive rumor clarification announcement, we calculated the daily CAR of positive rumors $[\mathrm{D}(1), \mathrm{D}(2), \mathrm{D}(3), \mathrm{D}(4)]$ and found that the $\mathrm{Z}$-value is no longer significant. 